\title{
nature
}

10 February 2000 Volume 403 Issue no 6770

\section{NSF boost sends the right message to Congress}

Clinton's belated decision to invest heavily in basic science and engineering at the National Science Foundation deserves to win the support of his political opponents on Capitol Hill.

$\mathrm{T}$ he United States, as Winston Churchill once observed, can usually be relied upon to do the right thing - after exhausting all of the other options available. The aphorism applies neatly to the research component of President Bill Clinton's eighth and last federal budget, which was delivered to the Congress on Monday.

The budget proposal would invest an additional $\$ 2.8$ billion in research and development, with most of the money being made available for university grants from the National Science Foundation (NSF) and the National Institutes of Health (NIH), the two agencies with the strongest track record of stringent peer review (see page 585). It also incorporates two major initiatives — in nanoscience and information technology - that will again place heavy emphasis on basic research conducted in universities.

The Clinton administration has acknowledged the need to shift the United States' massive research and development portfolio in the direction of peer-reviewed university research almost from the outset. Science in the National Interest, a report published by the White House Office of Science and Technology Policy in 1994, endorsed such a shift as the best way to extract maximum value from research dollars.

But the administration's economic advisers always held technology development efforts as the top priority in its research and development portfolio, and much political effort went into trying to expand such programmes, in the face of justified congressional scepticism. Less politically contentious, but equally insidious, was the administration's tendency to maintain support for intramural programmes, however unproductive, in government laboratories and research centres. Progress in strengthening non-biomedical university research has therefore been unnecessarily slow, and it is only now, with extra money available for government expenditure as a whole, thanks to the budget surplus, that decisive action can be taken to expand the NSF.

Not everyone agrees that this extra money is available, of course. Much of the $\$ 40$ billion of extra spending for the fiscal year 2001 contained in Clinton's budget proposal will be fiercely contested in the Congress, where some have already dismissed it as a pre-election spending binge.

But the research component of that plan is in pretty good shape. The NIH will, as usual, do better than the president suggests. And support for the NSF has broadened over the past three or four years. It used to struggle in the Congress because it has no big laboratories, and thus no natural constituency. But fiscal conservatives appreciate the NSF's efficiency and, provided its director, Rita Colwell, can persuade Congress that the nanoscience and information technology initiatives are consistent with NSF standards, its budget prospects are good.

The same cannot be said for the Department of Energy's component of the budget proposal. Most of that is for energy-related research, which the Republicans loathe, and for the Spallation Neutron Source, which they have chosen to associate with the political fortunes of Al Gore, the likely Democratic nominee in November's presidential election. But whoever wins that election will inherit a strong research portfolio that, one way and another, has strong bipartisan support.

\section{Think globally, act cautiously}

Renewed interest in a scientific approach to global problems is welcome, but needs sensitive treatment.

$\mathrm{O}$ ne of the most significant aspects of this year's World Economic Forum, the annual meeting of top politicians and business leaders that took place in Davos, Switzerland, last week, was the unusually high attention given to scientific and technological issues. Their prominence, expressed in forums and debates on topics ranging from childhood vaccination programmes to the neurosciences, provided a welcome recognition of the extent to which modern science now touches all aspects of our daily lives. There was also recognition - for example, in a surprise decision by business participants to put global warming at the top of their list of pressing global problems - that this involvement can be double-edged.

Behind the scenes, significant progress has been reported on discussions intended to place such debates on a more rigorous scientific footing. In particular, invited representatives of a selection of world scientific academies used the occasion to move forward plans, championed in particular by the US National Academy of Sciences, to create an Inter-Academy Center responsible for giving top-level, impartial scientific advice to governments on issues of global importance. A working group was set up to produce guidelines for creating such a centre. These will be debated — and hopefully approved — at a full meeting of scientific academies in Tokyo in May.

Any bid to inject greater scientific understanding into issues of global concern is to be welcomed. More would be achieved in mitigating the impact of global warming if there was a broader acceptance among political leaders of the scientific consensus on the potential dangers ahead. And the damaging spread of unscientific medical heresies, such as some alleged hazards of vaccination, continue to plague efforts to promote preventive health strategies in the Third World.

If there is a danger, it is that the agenda implicitly conveyed by this drive for more scientifically based decision-making may appear to be driven primarily by the most powerful actor on the international scene, the United States. Any initiative must reflect a plurality of approaches, not one that reflects the way such issues are seen from a single vantage point. Some are already nervous about the increased US presence in the International Council for Science (see page 582). Such fears may well prove unfounded. But given the power the United States wields as the world's strongest economy, it is essential that it and its scientists - wield this power sensitively. 